JAAKFE UNTAN

(Jurnal Audit dan Akuntansi Fakultas Ekonomi Universitas Tanjungpura)

Vol. 10 No. 1, Juni 2021

ISSN-P: (2252-7486), ISSN-E: (2746-6140)

https://jurnal.untan.ac.id/index.php/jaakfe

\title{
PENGARUH ADVERSE SELECTION, NEGATIVE FRAMING DAN GAYA KEPEMIMPINAN TERHADAP ESKALASI KOMITMEN (STUDI KASUS PADA MAHASISWA PRODI AKUNTANSI FAKULTAS EKONOMI DAN BISNIS UNIVERSITAS TANJUNGPURA PONTIANAK)
}

\author{
Dwi Prihatini ${ }^{1) *}$ \\ ${ }^{1)}$ Universitas Tanjungpura, Indonesia. \\ *E-mail: dwi.prihatini@ekonomi.untan.ac.id
}

\begin{abstract}
Abstrak
Tujuan dari penelitian ini adalah untuk menguji Pengaruh Adverse Selection, Negative Framing dan Gaya kepemimpinan Terhadap Eskalasi Komitmen Data yang digunakan dalam penelitian ini adalah data primer. Metode pengumpulan data dilakukan dengan eksperimen berupa kuisioner kepada partisipan. Populasi penelitian ini adalah seluruh Mahasiswa Akuntansi Angkatan 2016 Fakultas Ekonomi Dan Bisnis Universitas Tanjungpura Pontianak. Pemilihan sampel ini menggunakan teknik purposive sampling dan sampel yang diperoleh sebanyak 50 responden. Teknik analisis data yang dilakukan dengan metode Structural Equation Modelling (SEM) dengan pendekatan Partial Least Square (PLS) menggunakan perangkat lunak WarpPLS 6.0. Hasil penelitian menunjukkan bahwa Hasil penelitian ini menunjukkan bahwa Adverse Selection tidak memiliki pengaruh terhadap Eskalasi Komitmen, Negative Framing berpengaruh terhadap Eskalasi Komitmen dan penelitian ini menunjukkan bahwa Gaya Kepemimpinan tidak memiliki pengaruh terhadap Eskalasi Komitmen.
\end{abstract}

Kata kunci : Adverse Selection, Negative Framing, Gaya kepemimpinan, Eskalasi Komitmen.

Article History: Received:07-05-2021 Revised:-

Accepted:04-06-2021 
Vol. 10, No. 1 (Juni 2021)

Dwi Prihatini

DOI: http://dx.doi.org/10.26418/jaakfe.v10i1.46713

Hal 19-43

\section{LATAR BELAKANG MASALAH}

Peran manajer sangat berpengaruh dan penting dalam pengambilan keputusan untuk keberlangsungan perkembangan perusahaan terutama pada proyek investasi. rancangan manajer untuk membuat suatu keputusan yaitu, berbeda-beda tergantung pada konteks masalah yang sedang dihadapi oleh seorang manajer. Lubis (2010: 271) menjelaskan pengambilan keputusan merupakan suatu proses memilih salah satu pilihan di antara berbagai alternatif-alternatif tindakan yang akan berpengaruh terhadap masa depan. Manajer sabagai agen dari pemilik perusahaan harus memperhitungkan dan mempertimbangkan pilihan yang akan ditetapkan agar pilihan tersebut bukan merupakan keputusan yang salah bagi perusahaan.

Model pengambilan keputusan dikembangkan dengan asumsi bahwa keputusan didasarkan pada rasionalitas. Model rasionalitas menyatakan bahwa pengambil keputusan adalah manusia yang rasional, dimana mereka selalu konsisten dalam membuat pilihan didalam lingkup keterbatasan tertentu. Pengambilan keputusan berarti melakukan penilaian dan menetapkan pilihan. Pengambilan keputusan dikatakan sebagai tindakan seorang manajer dalam memecahkan suatu masalah yang sedang dihadapinya dengan cara memilih satu dari beberapa alternatif yang memungkinkan (Dubrin dan Andrew J, 2013).

Manajer proyek sering mengalami dilema atau kesulitan dalam membuat keputusan untuk menghentikan atau melanjutkan proyek investasi yang tidak menguntungkan bagi perusahaan. Beberapa tindakan menajer tersebut berupaya untuk tetap mempertahankan atau menyelamatkan proyek investasi hingga akhir dengan menambahkan dana (investasi tambahan) pada proyek investasi tersebut.

Manajer mengasumsikan jika penambahan dana untuk proyek investasi tersebut dapat menghasilkan pengembalian positif maka perusahaan tidak mengalami kerugian atau dana yang dikeluarkan untuk proyek investasi yang diberikan perusahaan tidak sia-sia. Sebaliknya, jika penambahan dana untuk proyek investasi tersebut menghasilkan pengembalian negatif maka perusahaan akan mengalami kerugian. Oleh karena itu, manajer sering mengalami perilaku bias atau perilaku yang tidak masuk akal yang terdorong untuk mempertahankan keputusan yang telah diambil sebelumnya hingga periode proyek tersebut berakhir, padahal keputusan tersebut dapat merugikan perusahaan atau organisasi.

Pengambilan keputusan tidak krusial adalah pengambilan keputusan ringan yang tidak mempunyai kebermaknaan dan akibat besar, sedangkan keputusan krusial merupakan keputusan yang mempunyai implikasi luas dan spektrum dengan determinasi tinggi. Dasar manajer untuk membuat suatu keputusan adalah berbeda-beda tergantung pada konteks masalah yang sedang dihadapi oleh manajer. Seorang manajer dalam mengambil atau membuat suatu keputusan dipengaruhi oleh beberapa faktor, antara lain: keadaan internal organisasi, ketersediaan informasi yang diperlukan, keadaan eksternal organisasi, kepribadian dan kecakapan dalam pengambilan sebuah keputusan. Ada beberapa hal yang harus diperhatikan oleh seorang pengambil keputusan, diantaranya: logika, rasional, pragmatis dan realita. 
Vol. 10, No. 1 (Juni 2021)

Dwi Prihatini

DOI: http://dx.doi.org/10.26418/jaakfe.v10i1.46713

Hal 19-43

Bazerman (1994) \& Staw (1981) dalam Jasrul (2015) menyebut perilaku tidak masuk akal ini sebagai nonrational escalation of commitmen dan syndrome decision errors yang berati suatu tindakan individu untuk mempertahankan komitmen terhadap keputusan yang telah dipilih sebelumnya hingga diluar batas rasional atau terpusat pada keputusan yang salah dari pembuat keputusan.

Penelitian Shulz dan Cheng (2002) menjelaskan tanggung jawab pribadi seseorang manajer (agen) merupakan salah satu faktor manajer melakukan eskalasi komitmen dimana manajer (agen) yang memiliki tanggung jawab penuh atau tinggi cenderung mengalami tingkat eskalasi komitmen lebih tinggi dibandingkan manajer yang memiliki tanggung jawab pribadi yang lebih rendah.

Menurut Handoko (2006) manajer pusat investasi jika diberikan tanggung jawab berarti manajer tersebut memiliki otoritas terhadap segala kegiatan manajemen pada investasi yaitu perencanaan, pengorganisasian dan pengambilan keputusan sehingga tanggung jawab yang dipikul manajer mendorong manajer untuk melakukan investasi tambahan yang berisiko.

Tanggung jawab dan wewenang tinggi yang terpusat pada pemimpin dalam pengambilan keputusan menggambarkan gaya kepemimpinan manajer otokratis. sedangkan manajer yang memiliki tingkat tanggung jawab yang rendah dengan tanggung jawab keberhasilan dipikul bersama-sama merupakan salah satu ciri-ciri gaya kepemimpinan manajer demokratis. Penelitian tentang tanggung jawab pribadi sebagai salah satu faktor kecenderungan eskalasi komitmen diIndonesia diteliti oleh Amilin (2003). Amilin dan Handoko (2006) yang menjelaskan manajer tersebut memiliki locus of control eksternal dan manajer dengan tanggung jawab besar akan melanjutkan proyek investasi karena manajer memiliki locus of control internal.

Eskalasi komitmen merupakan suatu pengambilan keputusan untuk meningkatkan atau memperluas komitmen terhadap suatu peroyek atau investasi tertentu meskipun proyek atau investasi tersebut mengindikasikan kegagalan. Eskalasi sering dikaitkan dengan prilaku pengabaian atas sinyal kegagalan. Ross \& Staw (1993) dalam Sari dan Wirakusuma (2016), menyebutkan bahwa penyebab timbulnya fenomena eskalasi diantaranya dipengaruhi oleh faktor-faktor seperti psikologis dan sosial, faktor organisasi, serta faktor proyek. Faktor psikologis dan sosial menunjukkan adanya sikap ego dan keinginan untuk menjaga reputasi diri yang membuat seseorang enggan mengakui kesalahan dan kegagalan. Faktor organisasi menunjukkan adanya permainan politik yang membawa pada minat terselubung yang ditunjukkan oleh beberapa orang berpengaruh dalam organisasi. sementara itu, faktor proyek lebih menunjukkan pada tinggkat return kegiatan bisnis yang tidak segera di capai. Manajer yang memiliki informasi yang privat akan bertindak sesuai kepentingan diri sendiri dan tidak memaksimalkan keuntungan yang diharapkan pemilik perusahaan, yakni dengan tetap melanjutkan pembiayaan proyek meskipun mengindikasikan bahwa manajer merasa memiliki ikatan emosional dan takut kredibilitasnya menurun jika proyek tersebut dihentikan ditengah jalan (Harrison dan Harrel,1993) dalam Sari dan Wirakusuma (2016). Hasil penelitian Rutledge dan Karim (1999) dalam Sari dan Wirakusuma (2016), bahwa manajer yang 
Vol. 10, No. 1 (Juni 2021)

Dwi Prihatini

DOI: http://dx.doi.org/10.26418/jaakfe.v10i1.46713

Hal 19-43

mengalami Adverse Selection akan melakukan Eskalasi Komitmen. Jensen dan Mecling (1976) dalam Sari dan Wirakusuma (2016), menjelaskan bahwa Adverse Selection adalah kondisi yang terjadi ketika terdapat ketidak seimbangan informasi yang disampaikan agen (manajer) kepada principal (pemilik perusahaan). Manajer dianggap mengetahui informasi lebih lengkap, mengenai kondisi internal perusahaan dibandingkan principal, akibatnya principal tidak mampu mengetahui apakah suatu keputusan yang diambil oleh manajer benarbenar didasarkan atas informasi yang sesungguhnya atau telah terjadi kelalaian tugas.

Kondisi ketidak seimbangan informasi antara pemilik perusahaan dengan manajer dan terdapat suatu kondisi untuk melalaikan tugas bagi manajer inilah kondisi yang membentuk suatu kondisi Adverse Selection (Gudono, 2012). Penelitian ini dilakukan pada Mahasiswa Program Sarjana Akuntansi Universitas Tanjungpura dengan teknik purposive sampling, yaitu telah menempuh mata kuliah akuntansi manajemen. Mahasiswa yang telah menempuh mata kuliah tersebut merupakan proksi manajer yang tepat karena dalam mata kuliah akuntansi manajemen diberikan teknik-teknik untuk menyajikan informasi yang akurat dan relevan agar dapat digunakan sebagai dasar dalam membuat perencanaan, pengendalian, dan pengambilan keputusan. Perbedaan ini dengan penelitian terdahulu adalah (2016) yang menggunakan Adverse Selection dan Negative Framing sebagai variabel independen dan variabel kecenderungan Eskalasi Komitmen sebagai variabel dependen, (2015) yang menggunakan Gaya Kepemimpinan dan Keefektifan Monitoring Kontrol sebagai variabel independen dan Eskalasi Komitmen dalam pengambilan keputusan investasi sebagai variabel dependen. Maka dalam penelitian ini memodifikasi kedua penelitian sebelumnya dengan menggunakan Adverse Selection, Negative Framing dan Gaya Kepemimpinan sebagai variabel independen, Eskalasi Komitmen sebagai variabel dependen.

\section{KAJIAN LITERATUR}

\section{Teori Keagenan}

Teori yang menjelaskan tentang Adverse Selection adalah teori keagenan. Teori keagenan yang berhubungan dengan masalah Eskalasi Komitmen pada pilihan tindakan yang gagal membuat manajer yang tidak berani mengambil risiko serta tindakannya tidak terawasi akan melaporkan berita bagus, manajer tersebut akan melaporkan berita buruk apabila berita tersebut diperlukan, karena berita buruk akan membuat karirnya terancam. Apabila informasi yang disajikan lengkap dalam kondisi incentive to shirk, maka manajer akan cenderung memilih untuk menghentikan proyek yang tidak menguntungkan atau merugikan karena hal ini akan segera diketahui oleh pemilik perusahaan. Sedangkan, jika manajer memiliki informasi privat, pemilik perusahaan tidak bisa mengawasi manajer secara keseluruhan, maka pada kondisi ini manajer yang memiliki incentive to shirk akan cenderung untuk melanjutkan proyek yang tidak menguntungkan atau merugikan. Kondisi ketika manajer memiliki informasi privat yang tidak dimiliki orang lain dalam perusahaan dan terdapat kesempatan untuk melalaikan tugas bagi manajer tersebut dapat dikatakan sebagai suatu kondisi Adverse Selection. 
Vol. 10, No. 1 (Juni 2021)

Dwi Prihatini

DOI: http://dx.doi.org/10.26418/jaakfe.v10i1.46713

Hal 19-43

Adverse Selection merupakan salah satu permasalahan yang disebabkan oleh adanya kesulitan pemilik perusahaan untuk memantau dan melakukan kontrol terhadap tindakan manajer, sehingga pemilik perusahaan tidak mengetahui dengan pasti apakah keputusan yang diambil oleh manajer berdasarkan pada informasi yang sesungguhnya atau tidak. Dalam teori keagenan terdapat masalah keagenan yang menjadi fokus utama dalam hubungan keagenan. Masalah keagenan yaitu masalah yang muncul ketika tujuan pemilik perusahaan dan manajer bertentangan dan akan menjadi tidak praktis ketika menimbulkan biaya yang mahal bagi pemilik perusahaan untuk memonitor perilaku manajer.

Manajer akan bertindak untuk kepentingan pribadinya dan manajer akan mengabaikan kepentingan perusahaan ketika ada dua kondisi terpenuhi, yaitu:

a. Adanya incentive to shirk, misalnya feedback manajer karena keputusan meneneruskan proyek lebih besar dibandingkan balas jasa karena menghentikannya.

b. Adanya informasi asimetri, yaitu manajer memiliki lebih banyak informasi dibandingkan pemilik perusahaan sehingga tidak sepenuhnya tahu tentang keadaan proyek.

Kondisi ini terjadi karena asimetri informasi yang terjadi antara prinsipal dan agen sehingga informasi yang diperoleh prinsipal kurang lengkap dan tidak dapat menjelaskan kinerja agen yang sesungguhnya dalam mengelola kekayaan prinsipal yang dipercayakan kepada agen (Sharp dan Salter,1997) dalam Sari dan Wirakusuma (2016).

Teori keagenan merupakan teori yang mendasari praktik bisnis perusahaan yang digunakan selama ini. Teori tersebut bermula dari gabungan teori ekonomi, teori keputusan, sosiologi, dan teori organisasi. Prinsip utama teori ini menyatakan adanya hubungan kerja antara pihak yang memberi wewenang yaitu investor dengan pihak yang menerima wewenang (agensi) yaitu manajer dalam bentuk kontrak kerja sama yang disebut "nexus of contract". Berdasarkan teori ini hubungan antara pemilik dan manajer pada dasarnya sulit tercipta karena adanya kepentingan yang saling bertentangan. Dari sudut pandang teori keagenan, prinsipal (pemilik) membawahi agen (karyawan atau manajer yang lebih rendah) untuk melaksanakan kinerja yang efisien (Masiyah Kholmi, 2010)

Pada sebagian besar organisasi, pengambilan keputusan didelegasikan dari level yang lebih tinggi dalam organisasi ke level yang lebih rendah. Teori keagenan mengasumsikan bahwa kinerja suatu organisasi ditentukan oleh usaha dan pengaruh kondisi lingkungan. Teori keagenan secara umum mengasumsikan bahwa prinsipal sebagai risk neutral dan agen sebagai risk and effort averse. Agen dan prinsipal dimotivasi oleh kepentingan sendiri dan seringkali kepentingan antara keduanya berbenturan. Menurut pandangan prinsipal, kompensasi yang diberikan kepada agen didasarkan pada hasil. Sedangkan menurut agen dia lebih suka kalau sistem kompensasi tersebut tidak semata-mata melihat hasil tetapi juga tingkat usahanya.

Teori keagenan dibangun sebagai upaya untuk memahami dan memecahkan masalah yang muncul jika ada ketidaklengkapan informasi pada saat melakukan kontrak. Jika manajer memiliki keunggulan informasi dibandingkan pemilik perusahaan serta kepentingan manajer dan pemilik perusahaan berbeda, maka akan terjadi masalah antara pemilik perusahaan 
Vol. 10, No. 1 (Juni 2021)

Dwi Prihatini

DOI: http://dx.doi.org/10.26418/jaakfe.v10i1.46713

Hal 19-43

dengan manajer dimana manajer akan melakukan tindakan yang menguntungkan dirinya sendiri namun merugikan pemilik perusahaan. Ketika kepentingan manajer bertentangan dengan kepentingan perusahaan, maka manajer memiliki insentif untuk melalaikan tugas. Insentif tersebut menjadikan manajer membuat keputusan yang bertentangan dengan kepentingan perusahaan. Model agensi mengasumsikan ketika manajer memiliki insentif mengabaikan kepentingan perusahaan, manajer harus memiliki kesempatan, dan ketersediaan informasi dapat menjadi sarana bagi kesempatan tersebut. Berdasarkan teori agensi semua individu bertindak atas kepentingan mereka sendiri.

\section{Teori Prospek}

Pengaruh frame atau framing adalah sebuah fenomena yang menunjukkan bahwa para pembuat keputusan akan merespon dengan cara yang berbeda pada permasalahan keputusan yang sama jika masalah tersebut disajikan dalam format yang berbeda (Kuhberger, 1998; Levin et al,; 1998) dalam Sari dan Wirakusuma . Yusnaini (2005) menyebutkan bahwa framing merupakan salah satu alasan penyebab terjadinya bias dalam pengambilan keputusan. Teori prospek merupakan salah satu teori yang mencoba menjelaskan pengaruh framing (Kahneman dan Tversky, 1979). Teori prospek dari Kahneman dan Tversky (1979) menjelaskan terjadinya bias kognitif yang mempengaruhi pengambilan keputusan dalam kondisi ketidak pastian dan berisiko. Individu akan bersifat menghindari risiko atau menyukai risiko tergantung dari masalah yang dihadapi. Teori ini berpendapat bahwa individu akan memberikan bobot yang berlebihan terhadap hasil yang pasti dari pada yang belum pasti. Kecenderungan ini menimbulkan perilaku menghindari risiko dalam kondisi pasti untung (Positive Framing). Dalam Positive Framing, individu menunjukkan penurunan preferensi risiko, dimana individu lebih berhati-hati dalam mengambil keputusan. Sebaliknya, individu lebih menyukai risiko dalam kondisi pasti rugi (Negative Framing). Negative Framing diproksikan dengan penyajian informasi mengenai kerugian yang pasti. Pengaruh sunk cost ternyata berperan cukup besar dalam proses pengambilan keputusan untuk tetap melanjutkan suatu investasi yang dianggap kurang menguntungkan. Sunk cost adalah biaya yang sudah terjadi di masa lalu dan tidak akan muncul lagi dari suatu proyek atau investasi baru (Putri, 2009). Sunk cost mempengaruhi pembuat keputusan dalam kondisi Negative Framing, sehingga mendorong individu menyukai risiko yang mengarah kepada Eskalasi Komitmen terhadap tindakan yang telah gagal (Keil et al. 2000).

Menurut Suartana (2005) framing adalah sebuah fenomena yang mengindikasikan pengambilan keputusan akan memberi respon dengan cara berbeda pada masalah yang sama jika disajikan dalam format berbeda. Framing atas informasi dapat mempengaruhi seseorang dalam pengambilan keputusan. Arnold (1997) dalam Sari dan Wirakusuma (2016) menjelaskan dalam literatur psikologi sering disebutkan bahwa cara suatu informasi disajikan kepada pembuat keputusan dapat mempengaruhi proses pembuatan keputusan itu sendiri. Dalam prospect theory, Kahneman \& Tversky (1979) dalam Sari dan Wirakusuma (2016). menyebutkan bahwa penyajian (framing) dari berbagai alternatif dapat mempengaruhi resiko outcome dari keputusan yang dibuat. Dari perspektif managerial accounting, manajer mempertimbangkan informasi akuntansi dan membuat keputusan yang berpengaruh terhadap 
Vol. 10, No. 1 (Juni 2021)

Dwi Prihatini

DOI: http://dx.doi.org/10.26418/jaakfe.v10i1.46713

Hal 19-43

masa depan perusahaan. Interpretasi awal dari informasi dapat menentukan informasi tembahan yang akan dipertimbangkan ketika membuat keputusan yang berkenaan dengan masa depan. Pada konteks keputusan terhadap proyek yang mengindikasikan kegagalan, biaya yang telah dikeluarkan (sunk cost) bertindak sebagai titik referensi bagi manajer dalam membuat keputusan. Fakta bahwa proyek mulai menunjukkan prospek yang negatif membawa pada beberapa kemungkinan diantaranya yaitu kemungkinan kerugian/keuntungan yang pasti terjadi (kerugian/keuntungan yang pasti terjadi masih berupa kemungkinan karena asumsi bahwa manajer masih belum mengambil keputusan untuk menghentikan/melanjutkan proyek) dan kemungkinan kerugian/keuntungan di masa mendatang yang kurang pasti. Ketika kemungkinan-kemungkinan tersebut diframing secara positif, maka informasi mengenai keuntungan akan lebih ditonjolkan. Ketika kemungkinan-kemungkinan tersebut diframing secara negatif, maka informasi mengenai kerugian yang akan lebih ditonjolkan.

\section{Teori Gaya Kepemimpinan Otoriter, Gaya Kepemimpin Partisipati dan Gaya Kepemimpinan Delegatif}

Teori gaya kepemimpinan otoriter, gaya kepemimpin partisipatif dan gaya kepemimpinan delegatif yang dikemukakan oleh Hasibuan (2016:172). Gaya kepemimpinan otoriter yaitu segala kebijakan dan keputusan terpusat pada pemimpin. Artinya bawahan hanya melaksanakan tugas yang telah diberikan oleh seorang pemimpin. Gaya kepemimpinan partisipatif yaitu pemimpin memberikan kesempatan kepada bawahan untuk ikut serta menyumbangkan saran, ide dan serta masukan dalam rangka pengambilan keputusan. Selanjutnya gaya kepemimpinan delegatif yaitu pemimpin memberikan kepercayaan kepada bawahan dalam menyelesaikan tugas karena bawahan tersebut dianggap memiliki kemampuan serta tingkat kematangan yang tinggi.

Pengambilan keputusan seringkali disamakan dengan proses berpikir, mengatur dan memecahkan masalah. Pengambilan keputusan merupakan suatu hasil atau keluaran dari proses mental atau kognitif yang membawa pada pemilihan suatu jalur tindakan diantara beberapa alternatif yang tersedia. Lubis $(2010$; 271) menjelaskan pengambilan keputusan merupakan suatu proses memilih salah satu pilihan diantara berbagai alternatif-alternatif tindakan yang akan berpengaruh terhadap masa depan. Manajer sebagai agen dari pemilik perusahaan harus memperhitungkan dan mempertimbangkan pilihan yang akan ditetapkan agar pilihan tersebut bukan merupakan keputusan yang salah untuk perusahaan.

Seorang manajer proyek sering mengalami dilema atau kesulitan dalam membuat keputusan untuk menghentikan atau melanjutkan proyek investasi yang tidak memiliki hasil bagi perusahaan. beberapa tindakan manajer tersebut berupaya untuk tetap mempertahankan atau menyalamatkan proyek investasi hingga akhir dengan menambahkan dana (investasi tambahan) pada proyek investasi tersebut. Thoha (2012) menyebutkan bahwa pengambilan keputusan adalah proses mengidentifikasi dan memilih serangkaian tindakan untuk menghadapi masalah tertentu atau mengambil keuntungan dari suatu kesempatan. Mengenai pengambilan keputusan terdapat berbagai macam definisi yang berbeda dari berbagai literatur mengenai pengambilan keputusan. pengambilan keputusan adalah tindakan manajer atau pimpinan untuk memecahkan masalah yang diantara alternatif-alternatif yang dimungkinkan. 
Vol. 10, No. 1 (Juni 2021)

Dwi Prihatini

DOI: http://dx.doi.org/10.26418/jaakfe.v10i1.46713

Hal 19-43

Sedangkan menurut Jasrul (2015) mendefinisikan pengambilan keputusan sebagai "proses memilih di antara berbagai alternatif tindakan yang berdampak pada masa depan".

\section{Self Justification Theory (Teori Pembenaran Diri)}

Self Justification Theory menjelaskan tentang tindakan manajer dalam melakukan eskalasi komitmen pengambilan keputusan investasi. Teori ini dipilih sebagai penjelasan yang paling relevan dalam Eskalasi Komitmen untuk pengambilan keputusan individu. Dalam self justification theory dijelaskan bahwa ketika manajer terlibat pada suatu proyek dari awal maka mereka akan cenderung untuk melanjutkan proyek tersebut, walaupun keadaan ekonomi menunjukkan bahwa proyek tersebut mengalami kerugian dibandingkan dengan manajer yang tidak terlibat dari awal. Adanya umpan balik negatif dan kebutuhan untuk membenarkan keputusan awal adalah dua kondisi yang menyebabkan orang melakukan eskalasi. Sedangkan menurut Tanjung (2012) Self Justification Theory merupakan teori yang menjelaskan manajer yang terlibat dari awal pada suatu proyek akan cenderung memilih untuk melanjutkan proyek hingga periode waktu proyek berakhir walaupun proyek tersebut mengalami kerugian.

Self Justification Theory menyatakan bahwa manajer yang bertanggung jawab untuk investasi sebelumnya tidak akan mengakui pada diri mereka sendiri atau orang lain bahwa penggunaan sumber daya mereka sebelumnya adalah salah. Mereka akan cenderung untuk meningkatkan komitmen karena harus membenarkan diri mereka sendiri terhadap keputusan sebelumnya yang mereka buat (Chong dan suryawati, 2010). Self Justification biasanya dijelaskan dengan teori kognitif disonan. Teori kognitif disonan menjelaskan bahwa ketika individu telah membuat keputusan awal mengenai suatu tindakan tertentu, umpan balik negatif merupakan disonan bagi keputusan awal tersebut. Sehingga meningkatkan komitmen terhadap keputusan awal tersebut merupakan salah satu cara untuk mengurang disonansi dengan keyakinan bahwa keuntungan akan dapat diraih dengan tindakan dan keputusan yang saat ini diambil.

Berdasarkan penjelasan tersebut, maka Self Justification Theory adalah suatu teori yang menjelaskan bagaimana seorang manajer (agen) akan tetap membenarkan dirinya atas tindakan Eskalasi Komitmen yang telah dilakukan atau manajer (agen) yang bertanggung jawab dan terlibat dari awal pada proyek investasi akan membenarkan keputusan sebelumnya hingga proyek tersebut berakhir walaupun keputusan tersebut adalah salah. Untuk mengurangi Eskalasi Komitmen yang disebabkan karena pembenaran diri perlu dilakukan sistem pemantauan yang membantu memeriksa persepsi pembuat keputusan sebelum keputusan atau pilihan berikutnya yangdibuat dapat terbukti bermanfaat.

\section{Hipotesis Penelitian}

\section{Pengaruh Adverse Selection Terhadap Eskalasi Komitmen}

Teori keagenan (Agency Theory) adalah teori yang dapat menjelaskan tentang adverse selection. Adverse Selection adalah salah satu permasalahan yang disebabkan adalah kesuliatan pemilik perusahaan atau investasi untuk mengawasi dan melakukan kontrol terhadap tindakan manajer, sehingga pihak pemilik perusahaan atau investasi tidak mengetahui dengan kepastian atau tindakan yang diambil oleh seorang manajer 
Vol. 10, No. 1 (Juni 2021)

Dwi Prihatini

DOI: http://dx.doi.org/10.26418/jaakfe.v10i1.46713

Hal 19-43

berdasarkan pada informasi atau data yang sesungguhnya atau tidak. Sharp dan Salter (1997) dalam Sari dan Wirakusuma (2016), menjelaskan bahwa kondisi ini terjadi karena asimetris informasi yang terjadi antara prinsipal dan agen sehingga informasi yang diperoleh prinsipal kurang lengkap dan tidak dapat menjelaskan kinerja agen yang sesungguhnya dalam mengelolah kekayaan prinsipal yang dipercayakan pada agen. Manajer memiliki informasi yang lengkap tentang iformasi didalam sebuah perusahaan atau investasi dan prospek perusahaan dimasa yang akan datang di bandingkan dengan pemilik perushaan atau investasi. Kondisi ketidak seimbangan informasi ini dinamakan informasi asimetris (asymmetric information). Informasi asimetris dapat menimbulkan permasalahan yang disebabkan adanya kesulitan pemilik untuk memonitoring dan melakukan kontrol terhadap tindakan-tindakan yang dilakukan manajer. Menurut Jansen dan Meckling (1976) dalam Sari dan Wirakusuma (2016), permaslahan tersebut adalah Adverse Selection, yaitu suatu keadaan dimana pemilik tidak dapat mengetahui apakah suatu keputusan yang diambil oleh manajer benar-benar didasarkan atas informasi yang telah diperolehnya atau terjadi kelalaian tugas (incentive to shrik).

\section{$\mathrm{H}_{1}$ : Adverse Selection memiliki pengaruh positif terhadap Eskalasi Komitmen}

2. Pengaruh Negative Framing terhadap Eskalasi KomitmenPengaruh frame atau framing adalah sebuah fenomena yang menunjukkan bahwa para pembuat keputusan yang sama jika masalah tersebut disajikan dalam format yang berbeda (Kuhberger, 1998; Levin et al.; 1998) dalam Sari dan Wirakusuma (2016). Yusnaini (2005) menyebutkan bahwa framing merupakan salah satu alasan penyebab terjadinya bias dalam pengambian keputusan. Teori prospek merupakan salah satu teori yang mencoba menjelaskan pengaruh framing (Khaneman dan Tversky, 1979) dalam Sari dan Wirakusuma (2016). Teori prospek (Prospect Theory) dari Kahneman dan Tversky (1979) dalam Sari dan Wirakusuma (2016), menjelaskan terjadinya bias kognitif yang mempengaruhi pengambilan keputusan dalam kondisi ketidak pastian dan berisiko. Individu akan bersifat menghindari risiko atau menyukai risiko tergantung pada masalah yang dihadapi. Teori ini berpendapat bahwa individu akan memberikan bobot yang berlebihan terhadap hasil yang pasti dari pada yang tidak pasti. Hal ini menimbulkan perilaku menghindari masalah dalam keadaan pasti untung (positive framing). Dalam positive framing, seseorang akan menunjukkan penurunan preferensi risiko, dimana seseorang lebih berhati-hati dalam mengambil keputusan. Sebaliknya, individu lebih menyukai risiko dalam kondisi pasti rugi (negative framing). Negative Framing diproksikan dengan penyajian informasi mengenai kerugian yang pasti. Sunk cost adalah biaya yang sudah terjadi dimasa lalu dan tidak akan muncul lagi dari suatu proyek atau investasi baru (Putri, 2009). Sunk cost memperngaruhi dalam pembuatan keputusan dalam kondisi negative framing, sehingga mendorong individu menyukai risiko yang mengarah Eskalasi Komitmen terhadap tindakkan yang telah gagal (Keil, 2000). Menurut Suratana (2005) framing adalah sebuah fenomena yang mengindikasikan pengambilan keputusan akan memberi respon dengan cara berbeda pada masalah yang sama jika disajikan dalam format berbeda. Arnold (1997) dalam Sari dan Wirakusuma (2016), menjelaskan dalam literatur psikologi sering disebutkan bahwa cara 
Vol. 10, No. 1 (Juni 2021)

Dwi Prihatini

DOI: http://dx.doi.org/10.26418/jaakfe.v10i1.46713

Hal 19-43

suatu informasi disajikan pada pembuatan keputusan dapat mempengaruhi proses pembuat keputusan itu sendiri. Berdasarkan uraian tersebut, maka dirumuskan hipotesis sebagai berikut:

\section{$\mathrm{H}_{2}$ : Negative Framing memiliki pengaruh positif terhadap Eskalasi Komitmen}

\section{Pengaruh Gaya Kepemimpinan terhadap Eskalasi Komitmen}

Peran manajer sangat berpengaruh dalam pengambilan keputusan untuk keberlangsungan perkembangan perusahaan terutama pada suatu proyek atau investasi. Pengambilan keputusan (decision making) menjadi salah satu faktor yang sangat penting dalam perusahaan dalam menjalankan suatu proyek atau investasi, merupakan suatu faktor untuk kegagalan atau keberhasilan seorang manajer dalam menetapkan pilihan untuk melanjutkan atau memberhentikan suatu proyek atau investasi. Lubis (2010;271) menjelaskan pengambilan keputusan merupakan proses memilih salah satu pilihan diantara berbagai alternatif-alternatif tindakan yang akan berpengaruh terhadap masa depan. Manajer sebagai agen dari pemilik perusahaan harus mampu memperhitungkan mempertimbangkan pilihan dalam hal pengambilan keputusan agar pilihan tersebut bukan merupakan keputusan yang salah untuk perusahaan agar tidak terjadinya kerugian. Manajer proyek seringkali mengalami kesulitan dalam mengambil keputusan untuk memberhentikan atau melanjutkan suatu proyek atau investasi yang tidak mengalami keuntungan bagi perusahaan. Bazerman (1994) dan Staw (1981) dalam Jasrul (2015), menyebut hal tidak masuk akal ini sebagai nonrational escalation of commitment dan syndrome of decision errors yang bertai suatu tindakan individu untuk mempertahankan komitmen terhadap keputusan yang telah dipilih sebelumnya hingga diluar batas rasional atau terpusat pada keputusan yang salah dari pembuat keputusan.

Shulz dan Cheng (2002), menjelaskan tanggung jawab pribadi seseorang manajer (agen) yang memiliki tanggung jawab penuh atau tinggi cenderung mengalami tingkat eskalasi komitmen lebih tingggi dibandingkan manajer yang memiliki tanggtung jawab yang lebih rendah. Berdasarkan uraian tersebut, maka dirumuskan hipotesis sebagai berikut:

\section{H3: Gaya Kepemimpinan memiliki pengaruh positif terhdapat Eskalasi Komitmen.}

\section{METODE PENELITIAN}

\section{Bentuk Penelitian}

Penelitian ini mengenai variabel pengaruh Adverse Selection, Negative Framing dan Gaya Kepemimpinan terhadap Eskalasi Komitmen. Metode yang digunakan dalam penelitian adalah metode analisis deskriptif statistik yang berfungsi untuk mendeskripsikan atau memberikan gambaran terhadap objek yang diteliti melalui data sampel atau populasi sebagaimana adanya, tanpa melakukan analisis dan membuat kesimpulan yang berlaku untuk umum (Sugiyono 2017).

Pendekatan yang digunakan adalah pendekatan kuantitatif yakni pendekatan yang memenuhi kaidah-kaidah ilmiah atau konkrit/empiris, objektif, terukur, rasional, sistematis 
Vol. 10, No. 1 (Juni 2021)

Dwi Prihatini

DOI: http://dx.doi.org/10.26418/jaakfe.v10i1.46713

Hal 19-43

dan replicable dapat diulang dan menggunakan angka-angka dan analisis statistik untuk menguji hubungan antar variable (sugiyono 2017).

\section{Data}

Jenis data yang digunakan ialah data primer yaitu bersumber langsung dari narasumber tanpa perantara. Dalam hal ini berupa jawaban dari beberapa pertanyaaan yang diberikan didalam kuesioner. Data primer yang dihasilkan merupakan tanggapan responden atas variable-variabel yang akan diuji.

\section{Populasi dan Sampel}

Dalam penelitian sampel kuantitatif, adalah bagian dari jumlah dan karakteristik yang dimiliki populasi. Dalam penelitian ini teknik pengambilan sample yang digunakan ialah Purposive Sampling dengan pertimbangan tertentu (Sugiyono,2017:144). Berdasarkan teknik tersebut, maka kriteria yang ditentukan adalah:

1. Mahasiswa yang telah lulus dalam mata perkuliahan akuntansi keprilakuan

2. Minimal memperoleh nilai B dalam mata perkuliahan tersebut

3. Mahasiswa merupakan mahasiwa akuntansi aktif berkuliah difakultas Ekonomi dan Bisnis Universitas Tanjungpura.

\section{Variabel Penelitian}

\section{Adverse Selection}

Adalah salah satu permasalahan yang disebabkan adanya kesulitan prinsipal (pemilik perusahaan) untuk memonitor dan melakukan kontrol terhadap tindakan agen (manajer), sehingga prinsipal tidak mengetahui dengan pasti apakah keputusan yang diambil agen didasarkan pada informasi yang sesungguhnya atau tidak, dengan tujuan agar penggunaan informasi yang dimiliki oleh pemilik perusahaan dapat mencegah tindakan manajer supaya tidak bertentangan dengan kepentingan perusahaan.

\section{Negative Framing}

Menurut (Suartana, 2005) sebuah fenomena yang mengindikasikan pengambilan keputusan akan memberi respon dengan cara berbeda pada masalah yang sama jika disajikan dalam format yang berbeda, dengan tujuan untuk menyelesaikan masalah yang sedang dihadapi oleh seorang manajer dalam memilih keputusan yang dihadapkan dalam kerugian atau untung pada suatu proyek atau investasi dan gaya kepemimpinan adalah manajer sebagai agen dari pemilik perusahaan harus memperhitungkan dan mempertimbangkan pilihan yang akan ditetapkan agar pilihan tersebut bukan keputusan yang salah untuk suatu perusahaan, karena manajer proyek sering mengalami dilema atau kesulitan dalam membuat keputusan untuk menghentikan atau melanjutkan proyek investasi yang tidak menguntungkan bagi pihak perusahaan.

\section{Gaya Kepemimpinan}

Seorang manajer proyek sering mengalami dilema atau kesulitan dalam membuat keputusan untuk menghentikan atau melanjutkan proyek investasi yang tidak memiliki hasil bagi perusahaan. beberapa tindakan manajer tersebut berupaya untuk tetap mempertahankan 
Vol. 10, No. 1 (Juni 2021)

Dwi Prihatini

DOI: http://dx.doi.org/10.26418/jaakfe.v10i1.46713

Hal 19-43

atau menyalamatkan proyek investasi hingga akhir dengan menambahkan dana (investasi tambahan) pada proyek investasi tersebut. Thoha (2012) menyebutkan bahwa pengambilan keputusan adalah proses mengidentifikasi dan memilih serangkaian tindakan untuk menghadapi masalah tertentu atau mengambil keuntungan dari suatu kesempatan. Mengenai pengambilan keputusan terdapat berbagai macam definisi yang berbeda dari berbagai literatur mengenai pengambilan keputusan. pengambilan keputusan adalah tindakan manajer atau pimpinan untuk memecahkan masalah yang diantara alternatif-alternatif yang dimungkinkan.

\section{Eskalasi Komitmen}

Eskalasi Komitmen dalam pengambilan keputusan suatu proyek atau investasi. Variabel ini menjadi fokus utama dalam penelitian yang sedang dilakukan. Eskalasi Komitmen adalah kecenderungan untuk bertahan atau berada pada tingkat tidak efektif untuk jangka waktu yang relatif lama. Eskalasi Komitmen terjadi dimana ketika seorang manajer memilih untuk tetap melanjutkan proyek investasi walaupun proyek atau investasi tersebut mengindikasikan kegagalan dan tidak memberika keuntungan bagi perusahaan tersebut.

\section{Metode pengumpulan Data}

Data penelitian ini didapatkan dengan melakukan sebuah penelitian eksperimen dan teknik pengumpulan data yang digunakan dalam penelitian ini.

adalah dengan menggunakan instrumen kasus untuk variabel Adverse Selection, negative framing dan gaya kepemimpinan. Kuesioner merupakan teknik pengumpulan data yang efisien bila peneliti tahu dengan pasti variabel yang akan diukur dan tahu apa yang diharapkan dari responden (Sugiyono,2017).

\section{Metode Analisis}

Penelitian ini menggunakan teknik pemodelan persamaan struktural (Structural Equation Modelling) yang dilakukan terhadap 2 (dua) model yaitu outer model dan inner model. Langkah-langkah analisis data dalam pendekatan PLS yaitu sebagai berikut: (1) merancang model pengukuran (outer model) yaitu model pengukuran yang menghubungkan indikator dengan variabel latennya dan (2) merancang model strukturan (inner model) yaitu model yang menghubungkan antara variabel laten dengan menggunakan software WarpPLS Versi 6.0.

\section{Uji Validitas Data}

Menurut Ghozali (2006:45-46), uji validitas digunakan untuk mengukur sah atau tidak validnya suatu kuesioner, sehingga suatu kuesioner dikatakan valid jika pertanyaan pada kuesioner mampu untuk mengungkapkan sesuatu yang akan diukur oleh kuesioner tersebut. Ada dua cara pengujian validitas, yaitu validitas konvergen dan validitas diskriminan. Uji validitas konvergen berhubungan dengan prinsip bahwa pengukur-pengukur dari suatu konstruk seharusnya berkolerasi tinggi. Dengan kata lain, apabila dua instrument tersebut memiliki korelasi yang tinggi. Sedangkan validitas diskriminan berhubungan dengan prinsip bahwa pengukur-pengukur konstruk yang berbeda seharusnya tidak berkorelasi tinggi (Hartono dan Abdilah,2014:60). 
Vol. 10, No. 1 (Juni 2021)

Dwi Prihatini

DOI: http://dx.doi.org/10.26418/jaakfe.v10i1.46713

Hal 19-43

\section{Uji Reabilitas Data}

Menurut Ghozali (2006:41-42), uji reliabilitas digunakan untuk mengukur suatu kuesioner yang merupakan instrument dari variabel atau konstruk, sehingga kuesioner diakatakan reliable atau handal jika jawabannya konsisten atau stabil dari waktu ke waktu. Uji reliabilitas dalam PLS dapat menggunakan dua metode, yaitu cronbach's alpha dan composite reliability. Menggunakan metode caronbach's alpha, suatu konstruk dikatakan reliable apabila nilainya $>0,6$ apabila menggunakan composite reliability, suatu konstruk dikatakan reliable apabila nilainya > 0,7 meskipun nilai 0,6 masih dapat diterima (Hartono dan Abdillah).

\section{Pengujian Inner Model}

Pengujian inner model merupakan structural untuk memprediksi hubungan kausalitas antar variabel laten. Model structural dalam PLS dievaluasi dengan menggunakan R squared untuk konstruk endogen. Q squared untuk penilaian validitas prediktif, dan nilai koefisien path atau $t$-values setiap path untuk uji signifikansi atar konstruk dalam model struktural. Hartono dan Abdillah (2014:63) menjelaskan bahwa semakin tinggi nilai R squared berarti semakin baik model prediksi dari model penelitian yang diajukan. Selanjutnya, nilai Q squared yang lebih besar dari nol menunjukkan validitas prediktif yang baik (Sholihin dan Ratmono,2013:73).

\section{Pengujian Hipotesis}

Uji hipotesis digunakan untuk menjelaskan arah hubungan antara variabel independen dan variabel dependennya. Pengujian ini dilakukan dengan analisis jalur (path analysis) atas model yang telah dibuat. Teknik SEM dapat secara simultan menguji model struktural yang komplek, sehingga dapat diketahui hasil analisis jalur dalam satu kali analisis regresi. Hasil korelasi antar konstruk diukur dengan melihat path coefficients dan tingkat signifikansinya yang kemudian dibandindengan hipotesis penelitian ini.

Suatu hipotesis dapat diterima atau harus ditolak secara statistik dapat dihitung melalui tingkat signifikansinya. Tingkat signifikansi yang dipakai dalam penelitian ini adalah sebesar $5 \%$. Dalam penelitian ini ada kemungkinan mengambil keputusan yang salah sebesar 5\% dan kemungkinan mengambil keputusan yang benar sebesar 95\%. Dasar pengambilan keputusan yaitu $\mathrm{p}$-value $\leq 0,05$ hipotesis diterima sebaliknya $\geq 0,05$ hipotesis ditolak.

\section{HASIL PENELITIAN DAN PEMBAHASAN}

\section{Validitas Konvergen}

Validitas konvergen dapat dilihat dari koefisien kolerasi antara skor indikator reflektif dengan skor variabel latennya. Pada analisis faktor, hal ini dapat dilihat pada nilai muatan (factor loading). beberapa ilmuan menyebutkan bahwa jika nilai muatan faktor lebih besar sama dengan 0,5 sampai dengan 0,6 dianggap cukup sebagai kriteria terpenuhinya validitas konvergen, hal ini berlaku jika banyak indikator masing-masing variabel berkisar antara 3 
Vol. 10, No. 1 (Juni 2021)

Dwi Prihatini

DOI: http://dx.doi.org/10.26418/jaakfe.v10i1.46713

Hal 19-43

sampai dengan 7. Bahkan Hair et al. (2010) memberikan rule of thumb muatan faktor dipandang bermakna jika lebih besar sama dengan 0,30.

Tabel 1

Combined Loadings and Cross-Loadings

\begin{tabular}{|c|c|c|c|c|c|}
\hline & AS & $\mathrm{NF}$ & GP & EP & P Value \\
\hline AS1 & 1000 & 0.000 & 0.000 & -0.000 & $<0.001$ \\
\hline NF1 & 0.064 & 0.843 & -0.057 & -0.115 & $<0.001$ \\
\hline NF2 & -0.064 & 0.843 & 0.057 & 0.115 & $<0.001$ \\
\hline GP1 & -0.831 & 1.288 & 0.523 & -0.508 & $<0.001$ \\
\hline GP2 & -0.557 & 0.655 & 0.602 & -0.123 & $<0.001$ \\
\hline GP3 & -0.255 & 0.274 & 0.597 & -0.222 & $<0.001$ \\
\hline GP4 & -0.335 & 0.363 & 0.494 & -0.419 & $<0.001$ \\
\hline GP5 & 0.988 & -0.789 & 0.578 & 0.270 & $<0.001$ \\
\hline GP6 & 0.306 & -0.172 & 0.511 & 0.104 & $<0.001$ \\
\hline GP7 & 0.778 & -0.674 & 0.287 & 0.534 & 0.015 \\
\hline GP8 & 0.080 & -0.093 & 0.618 & -0.290 & $<0.001$ \\
\hline GP9 & 0.266 & -0.294 & 0.586 & 0.218 & $<0.001$ \\
\hline GP10 & 0.769 & -0.617 & 0.422 & 0.383 & $<0.001$ \\
\hline GP11 & 0.055 & -0.808 & 0.384 & 0.444 & 0.002 \\
\hline GP12 & -0.026 & 0.064 & 0.737 & -0.184 & $<0.001$ \\
\hline GP13 & 0.245 & -0.358 & 0.753 & 0.077 & $<0.001$ \\
\hline GP14 & -0.453 & 0.512 & 0.795 & -0.051 & $<0.001$ \\
\hline GP15 & -0.313 & -0.081 & 0.703 & 0.218 & $<0.001$ \\
\hline EP1 & 0.000 & -0.000 & -0.000 & 1.000 & $<0.001$ \\
\hline
\end{tabular}

Sumber: Output olah data WarpPLS 6.0

Berdasarkan tabel diatas, dapat diketahui bahwa terdapat indikator yang tidak memenuhi validitas konvergen karena tidak memenuhi nilai muatan faktor yang dihasilkan untuk setiap indikator lebih dari 0,30. Selain itu terdapat beberapa indikator lainnya yang membuat distribusi data menjadi tidak normal sehingga dari total 19 indikator, penulis menghapus indikator yaitu (GP7, GP10, GP11) dan tersisa 16 indikator dengan susunan berikut:

Tabel 2

Combined Loadings And Cross-Loadings (Setelah Di Drop)

\begin{tabular}{|c|c|c|c|c|c|}
\hline & AS & NF & GP & EP & P Value \\
\hline AS1 & $\mathbf{1 . 0 0 0}$ & 0.000 & -0.000 & -0.000 & $<0.001$ \\
\hline NF1 & 0.050 & $\mathbf{0 . 8 4 3}$ & -0.059 & -0.126 & $<0.001$ \\
\hline NF2 & -0.050 & $\mathbf{0 . 8 4 3}$ & 0.059 & 0.126 & $<0.001$ \\
\hline GP1 & -0.736 & 1.195 & $\mathbf{0 . 5 6 0}$ & -0.457 & $<0.001$ \\
\hline GP2 & -0.445 & 0.485 & $\mathbf{0 . 6 3 3}$ & -0.019 & $<0.001$ \\
\hline GP3 & -0.204 & 0.224 & $\mathbf{0 . 6 0 2}$ & -0.195 & $<0.001$ \\
\hline
\end{tabular}


Vol. 10, No. 1 (Juni 2021)

Dwi Prihatini

DOI: http://dx.doi.org/10.26418/jaakfe.v10i1.46713

Hal 19-43

\begin{tabular}{|c|c|c|c|c|c|}
\hline GP4 & -0.330 & 0.313 & $\mathbf{0 . 5 0 5}$ & -0.383 & $<0.001$ \\
\hline GP5 & 1.055 & -0.811 & $\mathbf{0 . 5 4 5}$ & 0.275 & $<0.001$ \\
\hline GP6 & 0.138 & -0.001 & $\mathbf{0 . 4 5 4}$ & 0.008 & $<0.001$ \\
\hline GP8 & 0.087 & -0.144 & $\mathbf{0 . 6 1 7}$ & -0.254 & $<0.001$ \\
\hline GP9 & 0.321 & -0.390 & $\mathbf{0 . 5 7 4}$ & 0.297 & $<0.001$ \\
\hline GP12 & 0.094 & -0.082 & $\mathbf{0 . 7 4 8}$ & -0.097 & $<0.001$ \\
\hline GP13 & 0.041 & -0.550 & $\mathbf{0 . 7 6 1}$ & 0.190 & $<0.001$ \\
\hline GP14 & -0.203 & 0.204 & $\mathbf{0 . 8 2 8}$ & 0.133 & $<0.001$ \\
\hline GP15 & -0.139 & -0.285 & $\mathbf{0 . 7 1 3}$ & 0.337 & $<0.001$ \\
\hline EP1 & 0.000 & -0.000 & -0.000 & $\mathbf{1 . 0 0 0}$ & $<0.001$ \\
\hline
\end{tabular}

Sumber: Output olah data WarpPLS 6.0

\section{Validitas Diskriminan}

Validitas diskriminasi dapat dilihat dari nilai loading dan cross loading. Bilamana nilai loading setiap indikator pada variabel bersangkutan lebih besar dibandingkan dengan cross loading pada variabel laten lainnya maka dikatakan memenuhi validitas diskriminan. Motode untuk melihat validitas diskriminan keseluruhan indikator secara bersama-sama (kuesioner) dapat dilihat dengan membandingkan nilai square root of average variance extracted (AVE) setiap variabel laten dengan korelasi antar variabel laten bersangkutan dengan variabel laten lainnya. Bilamana akan AVE (pada diagonal utama) lebih besar dari korelasi variabel yang bersangkutan, maka terpenuhi validitas diskriminan (Solimun dan Fernandes, 2017).

Tabel 3

Akar AVE dan Koefisien Korelasi

\begin{tabular}{|c|c|c|c|c|}
\hline & AS & NF & GP & EP \\
\hline AS & $\mathbf{( 1 . 0 0 0 )}$ & 0.755 & 0.109 & 0.331 \\
\hline NF & 0.755 & $\mathbf{( 0 . 8 4 3 )}$ & 0.117 & 0.513 \\
\hline GP & 0.109 & 0.117 & $\mathbf{( 0 . 6 9 0 )}$ & 0.086 \\
\hline EP & 0.331 & 0.513 & 0.086 & $\mathbf{( 1 . 0 0 0 )}$ \\
\hline
\end{tabular}

Sumber: Output Olah Data WarpPLS 6.0

Berdasarkan table diatas dapat diketahui bahwa validitas diskriminasi setiap indikator terpenuhi karena nilai akar AVE (pada diagonal utama) lebih besar dari korelasi variabel tersebut. Misalnya variabel AS memiliki akar AVE 1.000: korelasinya dengan variabel lain $0.755,0.109,0.331$ sehingga dapat dikatakan indikator AS telah memenuhi validitas diskriminan.

\section{Uji Reliabilitas}

Uji reliabilitas dalam PLS menggunakan metode dengan composite reliability dan cronbach's Alpha. Suatu konstruk dalam kedua metode tersebut dikatakan reliable apabila nilainya $\mathrm{CR}>0,7$ dan cronbach's Alpha $>0.6$. 
Vol. 10, No. 1 (Juni 2021)

Dwi Prihatini

DOI: http://dx.doi.org/10.26418/jaakfe.v10i1.46713

Hal 19-43

Tabel 4

Laten Variabel Coefficients (WarpPLS 6.0)

\begin{tabular}{|c|c|c|c|c|}
\hline & AS & NF & GP & EP \\
\hline R-squared & & & & 0.346 \\
\hline Adj. R-squared & & & & 0.302 \\
\hline Composite reliab. & 1.000 & 0.830 & 0.889 & 1.000 \\
\hline Cronbach's alpha & 1.000 & 0.592 & 0.857 & 1.000 \\
\hline Avg. Var. extrac. & 1.000 & 0.710 & 0.476 & 1.000 \\
\hline Full Collin. VIF & 2.355 & 2.845 & 1.016 & 1.372 \\
\hline q-squared & & & & 0.302 \\
\hline Min & -1.864 & -2.166 & -1.539 & -1.670 \\
\hline Max & 1.450 & 1.952 & 1.707 & 1.797 \\
\hline Median & 0.124 & -0.095 & -0.327 & 0.410 \\
\hline Mode & 0.124 & -0.519 & -0.937 & 0.410 \\
\hline Skewness & -0.559 & 0.178 & 0.384 & -0.236 \\
\hline Exc. Kurtosis & -0.657 & -0.457 & -1.263 & -0.927 \\
\hline Unimodal-RS & Yes & Yes & Yes & Yes \\
\hline Unimodal-KMV & Yes & Yes & Yes & Yes \\
\hline Normal-JB & Yes & Yes & Yes & Yes \\
\hline Normal-RJB & Yes & Yes & Yes & Yes \\
\hline Histogram & View & View & View & View \\
\hline
\end{tabular}

Sumber: Output Olah Data WarpPLS 6.0

Berdasarkan tabel diatas dapat dilihat $R$-squared menunjukkan berapa proposi variabel respon yang dapat dijelaskan oleh variabel prediktor. Semakin tinggi $R$-squared maka model semakin baik, dan juga sebaliknya. $R$-squared hanya ada untuk variabel respon (Solimun dan Fernandes, 2017). Berdasarkan tabel 4.7 diperoleh nilai $R$-squared untuk variabel depanden Eskalasi Komitmen (EP) sebesar 0.346 artinya kontribusi pengaruh variabel Adverse Selection (AS), Negative Framing (NF), Gaya Kepemimpinan (GP) yaitu sebesar 34,6\% dan sisanya $65,4 \%$ dipengaruhi oleh variabel lain dalam penelitian ini. Adjusted $R$-squared merupakan nilai $R$-squared yeng telah disesuaikan, berdasarkan tabel diatas diperoleh nilai adjusted $R$ squared untuk variabel EP sebesar 0.302 hal ini membuktikan bahwa pengaruh variabel AS, NF dan GP terhadap EP adalah sebesar 30,2\% dan sisanya 69,8\% dipengaruhi oleh faktor lainnya.

Berdasarkan tabel diatas menunjukkan Nilai Average Variance Extracted (AVE) untuk semua variabel memiliki nilai diatas 0.50 . Berdasarkan table diatas diketahui bahwa semua variabel dalam penelitian model penelitian ini telah memenuhi kriteria validitas konvergen (convergent validity). Full collinearity VIF merupakan hasil pengujian kolinearitas penuh yang meliputi multikolinearitas vertikal dan lateral. Kolonearitas lateral yaitu kolearitasantara variabel laten prediktor dengan kriteria dan dapat digunakan untuk menguji commond method bias. Kriteria untuk full collinearity test adalah harus bernilai $<3,3$ (Solimun dan Fernandesz,2017). Berdasarkan tabel diatas dapat diketahui bahwa full collinearity test untuk 
Vol. 10, No. 1 (Juni 2021)

Dwi Prihatini

DOI: http://dx.doi.org/10.26418/jaakfe.v10i1.46713

Hal 19-43

semua variabel bernilai $<3,3$, sehingga model bebas dari masalah kolinearitas vertikal, lateral, dan common method bias.

Berdasarkan tabel diatas tersebut menunjukkan bahwa $Q$-squared digunakan untuk penilaian validitas prediktif atau relevansi dari sekumpulan variabel laten prediktor pada variabel kriterion. $Q$-squared dapat bernilai negatif sedangkan nilai $Q$-squared selalu positif. Model dengan validitas prediktif harus mempunyai nilai $Q$-squared lebih besar dari nol (Solimun dan Fernandesz,2017). Hasil estimasi tabel diatas menunjukkan validitas prediktif karena 0.302 lebih besar dari pada nol.

Tabel 5

Composite Reliability Dan Cronbach's Alpha

\begin{tabular}{|c|c|c|}
\hline Variabel & $\begin{array}{c}\text { Composite reliability } \\
\text { Coefficients }\end{array}$ & $\begin{array}{c}\text { Cronbach's alpha } \\
\text { coefficients }\end{array}$ \\
\hline AS & 1.000 & 1.000 \\
\hline NF & 0.830 & 0.592 \\
\hline GP & 0.889 & 0.857 \\
\hline EP & 1.000 & 1.000 \\
\hline
\end{tabular}

Sumber: Output Olah Data WarpPLS 6.0

Berdasarkan tabel diatas Composite Reliability Dan Cronbach's Alpha dapat diketahui bahwa: Adverse Selection memiliki nilai composite reliability sebesar 1.000, maka Adverse Selection dapat dikatakan reliable karena memiliki nilai $>0.70$. Nilai cronbach's alpha untuk Adverse Selection sebesar 1.000.

1. Negative Framing memiliki nilai composite reliability sebesar 0.830, maka Negative Framing dapat dikatakan reliable karena memiliki nilai $>0.70$. Nilai cronbach's alpha untuk Negative Framing sebesar 0.592 artinya reliable untuk melakukan pengujian karena memiliki nilai $>0.60$.

2. Gaya Kepemimpinan memiliki nilai composite reliability sebesar 0.889 , maka Gaya Kepemimpinan dapat dikatakan reliable karena memiliki nilai $>0.70$. Nilai cronbach's alpha untuk Gaya Kepemimpinan sebesar 0.857 artinya reliabel untuk melakukan pengujian karena memiliki nilai $>0.60$.

3. Eskalasi Komitmen memiliki nilai composite reliability sebesar 1.000, maka Eskalasi Komitmen dapat dikatakan reliabel karena memiliki nilai $>0.70$. Nilai cronbach's alpha untuk Eskaslasi Komitmen sebesar 1.000 artinya reliabel untuk melakukan pengujian karena memiliki nilai $>0.60$.

Tabel 6

Model Fit dan Quality Indices

\begin{tabular}{|c|l|c|c|c|}
\hline No & \multicolumn{1}{|c|}{ Model fit dan Quality indices } & Kriteria fit & Hasil analisis & Keterangan \\
\hline 1. & Average path coefficient (APC) & $\mathrm{P}<0.05$ & $0.249,(\mathrm{P}=0.015)$ & Baik \\
\hline 2. & Average R-squared (ARS) & $\mathrm{P}<0.05$ & $0.346,(\mathrm{P}=0.002)$ & Baik \\
\hline 3. & $\begin{array}{l}\text { Average adjusted R-squared } \\
\text { (AARS) }\end{array}$ & $\mathrm{P}<0.05$ & $0.302,(\mathrm{P}=0.005)$ & Baik \\
\hline 4. & Average block VIF (AVIF) & $\begin{array}{l}\text { Acceptable if }<= \\
5, \text { ideally }<=3,3\end{array}$ & $\begin{array}{l}1.802, \text { acceptable } \\
\text { if }<=5, \text { ideally }<= \\
3.3\end{array}$ & Ideal \\
\hline
\end{tabular}


Vol. 10, No. 1 (Juni 2021)

Dwi Prihatini

DOI: http://dx.doi.org/10.26418/jaakfe.v10i1.46713

Hal 19-43

\begin{tabular}{|c|l|c|c|c|}
\hline 5. & Average full collinearty VIF \\
(AFVIF) & $\begin{array}{c}\text { Acceptable if }<=5 \\
\text { ideally }<=3,3\end{array}$ & $\begin{array}{c}1.897, \text { acceptable } \\
\text { if }<=5, \text { ideally }<= \\
3.3\end{array}$ & Ideal \\
\hline 6. & Tenenhaus GoF (GoF) & $\begin{array}{c}\text { Kecil }>=0.1, \\
\text { Sedang }>=0.25, \\
\text { besar }>=0.36\end{array}$ & $\begin{array}{c}0.525, \text { small }>= \\
0.1, \text { medium }>= \\
0.25, \text { large }>=0.36\end{array}$ & Besar \\
\hline 7. & Sympson's paradox ratio (SPR) & $\begin{array}{c}\text { Acceptable if }>= \\
0.7, \text { ideally }=1\end{array}$ & $\begin{array}{c}1.000, \text { acceptable } \\
\text { if }>=0.7, \text { ideally }= \\
1\end{array}$ & Ideal \\
\hline 8. & $\begin{array}{l}\text { R-aquared contribution ratio } \\
\text { (RSCR) }\end{array}$ & $\begin{array}{c}\text { Acceptable if }>= \\
0.9, \text { ideally }=1\end{array}$ & $\begin{array}{c}1.000, \text { acceptable } \\
\text { if }>=0.9, \text { ideally }= \\
1\end{array}$ & Ideal \\
\hline 9. & Statistical suppression ratio (SSR) & $\begin{array}{c}\text { Acceptable if }>= \\
0.7\end{array}$ & $\begin{array}{c}1.000, \text { acceptable } \\
\text { if }>=0.7\end{array}$ & Ideal \\
\hline 10. & $\begin{array}{l}\text { Nonlinear bivariate causality } \\
\text { direction ratio (NLBCDR) }\end{array}$ & $\begin{array}{c}\text { Acceptable if }>= \\
0.7\end{array}$ & $\begin{array}{c}0.667, \text { acceptable } \\
\text { if }>=0.7\end{array}$ & Ideal \\
\hline
\end{tabular}

Sumber: Output Olah Data WarpPLS 6.0

Berdasarkan tabel diatas Model Fit dan Quality Indices;

Batas yang dapat diterima untuk nilai APC, ditentukan oleh p-value yang dihasilkan yaitu $\leq 0.05$. Berdasarkan tabel diatas diperoleh nilai $\mathrm{APC}=0.249$ dan $\mathrm{P}=0.015$, sehingga dapat disimpulkan model yang dibangun dalam penelitian ini dapat memenuhi syarat signifikansi (Solimun dan Fernandes, 2017).

Batas nilai yang dapat diterima oleh nilai ARS, ditentukan oleh $\mathrm{p}$-value yang dihasilkan yaitu $\leq 0.05$. berdasarkan tabel diatas diperoleh nilai $\mathrm{ARS}=0.346$, dan $(\mathrm{P}=0.002)$, hal ini menunjukkan bahwa model yang dibangun dalam penelitian ini dapat memenuhi syarat signifikansi (Solimun dan Fernandes, 2017).

Batas nilai yang dapat diterima oleh nilai AARS, ditentukan oleh p-value yang dihasilkan yaitu $\leq 0.05$. berdasarkan tabel diatas diperoleh nilai $A A R S=0.302$, dan $(P=0.005)$. dengan demikian dapat disimpulkan bahwa model yang dibangun dalam penelitian ini dapat memenuhi syarat signifikansi (Solimun dan Fernandes, 2017).

Batas nilai ideal AVIF adalah $\leq 3.3$ dan masih bisa diterima dan ditoleransi sampai pada nilai 5. Berdasarkan tabel diatas diperoleh nilai $\mathrm{AVIF}=1.802$ artinya masuk pada kategori nilai yang ideal, maka dapat disimpulkan bahwa model yang dibangun dalam penelitian ini tidak terjadi multikolinearitas (Solimun dan Fernandes, 2017).

Batas nilai ideal AFVIF adalah $\leq 3.3$ dan masih bisa diterima/ditoleransi sampai pada nilai 5. Berdasarkan tabel diatas diperoleh nilai $\mathrm{AFVIF}=1.897$, artinya masuk pada kategori nilai yang ideal, hal ini dapat disimpulkan model yang dibangun dalam penelitian ini tidak terjadi multikolinearitas (Solimun dan Fernandes, 2017).

Batas nilai GoF mempunyai tiga kategori yaitu $\geq 0.1$, menengah $\geq 0.25$ dan besar $\geq 0.36$. berdasarkan tabel diatas diperoleh $\mathrm{GoF}=0.525$, artinya masuk pada nilai dengan kategori nilai yang besar, jadi dapat disimpulkan bahwa kekuatan model dalam penelitian ini melakukan prediksi yang besar (Solimun dan Fernandes, 2017).

Batas nilai SPR adalah 1 dan masih dapat diterima/ditoleransi apabila $\geq 0.7$, berdasarkan tabel diatas diperoleh nilai $\mathrm{SPR}=1.000$, artinya masuk pada kategori nilai yang 
Vol. 10, No. 1 (Juni 2021)

Dwi Prihatini

DOI: http://dx.doi.org/10.26418/jaakfe.v10i1.46713

Hal 19-43

ideal, jadi dapat disimpulkan bahwa model penelitian ini mampu menjelaskan hubungan kualitas antar variabel (Solimun dan Fernandes, 2017).

Batas nilai RSCR adalah 1 dan masih dapat diterima/ditoleransi apabila $\geq 0.9$ berdasarkan tabel diatas diperoleh nilai $\mathrm{RSCR}=1.000$, artinya masuk pada kategori nilai yang ideal, jadi dapat disimpulkan bahwa model penelitian ini mampu menunjukkan kemampuan variabel prediktor dalam menjelaskan variabel respon (Solimun dan Fernandes, 2017).

Batas nilai idela SSR adalah 1 dan masih dapat diterima/ditoleransi apabila $\geq 0.7$, berdasarkan tabel diatas diperoleh nilai $\mathrm{SSR}=1.000$, artinya masuk pada kategori nilai ideal, jadi dapat disimpulkan bahwa model penelitian ini mampu menjelaskan hubungan kausalitas antar variabel (Solimun dan Fernandes, 2017).

Batas nilai ideal NLBCDR adalah 1 dan masih dapat diterima/ditoleransi apabila $\geq 0.7$, berdasarkan tabel diatas diperoleh nilai $\mathrm{NLBCDR}=0.667$, artinya masuk pada kategori nilai diterima, jadi dapat disimpulkan bahwa model penelitian ini mampu menjelaskan hubungan kausalitas antar variabel (Solimun dan Fernandes, 2017)

\section{Inner Model}

Koefisien Determinasi (R-Square)

Gambar 2

Koefisien Determinasi

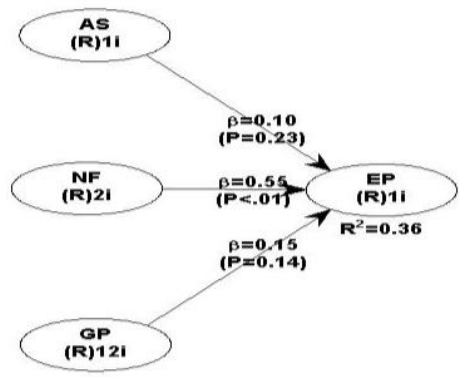

\begin{tabular}{|ll|}
\hline Keterangan & $:$ \\
AS & $:$ Adverese Selection \\
NF & $:$ Negative Framing \\
GP & $:$ Gaya Kepemimpinan \\
EP & $:$ Eskalasi Komitmen \\
\hline
\end{tabular}

Sumber: Data olahan (2020)

Tabel 7

Ukuran Koefisien Determinasi (R-Square)

\begin{tabular}{|c|c|}
\hline Variabel & R-Square \\
\hline Eskalasi komitmen & 0.36 \\
\hline
\end{tabular}

Sumber: Data Olahan (2020)

Berdasarkan tabel diatas dapat dilihat nilai R-Square adalah sebesar 0.36 atau $36 \%$ yang berati bahwa Adverse Selection, Negative Framing dan Gaya Kepemimpinan dalam menjelaskan pengaruhnya terhadap Eskalasi Komitmen adalah sebesar 36\% sedangkan sisanya $64 \%$ dijelaskan oleh faktor lain diluar model penelitian ini. 
Vol. 10, No. 1 (Juni 2021)

Dwi Prihatini

DOI: http://dx.doi.org/10.26418/jaakfe.v10i1.46713

Hal 19-43

\section{Relevansi Prediksi (Q-Square)}

Relevansi prediksi Q-Square bertujuan untuk mengukur seberapa baik nilai pengamatan oleh model dan juga estimasinya. Relevansi prediksi dianggap baik jika nilai Q-Square >0, jika hasil Q-Square $<0$ artinya model penelitian tidak relevan. Adapun hasil dari perhitungan menggunakan software WarpPLS 6.0 adalah sebagai berikut

Tabel 8

Ukuran Q-Square

\begin{tabular}{|c|c|}
\hline Variabel & Q-Square \\
\hline Eskalasi Komitmen & 0.302 \\
\hline
\end{tabular}

Sumber: Data Olahan (2020)

Dari tabel diatas dapat dilihat bahwa Q-Square dari eskalasi komitmen (Y) adalah sebesar 0.302 dengan demikian dapat disimpulkan bahwa model dalam penelitian ini adalah relevan.

\section{Hasil Penelitian}

\section{Hasil Pengujian Hipotesis}

Pengujian hipotesis pada analisis SEM-PLS menggunakan uji -1 dibantu dengan software WarpPLS 6.0, kaidah pengujian hipotesis yaitu dilakukan dengan t-test. Kaidah keputusan dilakukan bila diperoleh p-value $\leq 0.05$ maka dikatakan significant.

\section{Tabel 9}

Hasil Pengujian Hipotesis

\begin{tabular}{|c|c|c|c|c|c|c|}
\hline No & Hipotesis & \multicolumn{2}{|c|}{$\begin{array}{c}\text { Hubungan antara Variabel } \\
\text { (variabel penjelas } \rightarrow \\
\text { Variabel Respon }\end{array}$} & Koef $\boldsymbol{\beta}$ & P-value & keterangan \\
\hline 1. & H1 & AS & EP & 0.100 & 0.234 & Tidak Signifikan \\
\hline 2. & H2 & NF & EP & 0.546 & 0.001 & Signifikan \\
\hline 3. & H3 & GP & EP & 0.150 & 0.136 & Tidak Signifikan \\
\hline
\end{tabular}

Sumber: Output Olah Data WarpPLS 6.0

Berdasarkan tabel diatas menggunakan WarpPLS 6.0, dapat diketahui:

1. Hasil penelitian ini menunjukkan nilai koefisien korelasi antara Adverse Selection dan Eskalasi Komitmen sebesar 0.100 dengan tingkat signifikansi sebesar 0.234. Hal ini menunjukkan bahwa Adverse Selection memiliki pengaruh positif dan tidak signifikan terhadap Eskalasi Komitmen maka dinyatakan bahwa H1 ditolak.

2. Hasil penelitian ini menunjukkan nilai koefisien korelasi antara korelasi antara Negative Framing dan Eskalasi Komitmen sebesar 0.546 dengan tingkat signifikansi sebesar 0.001. Hal ini menunjukkan bahwa Negative Framing memiliki pengaruh positif dan signifikan terhadap Eskalasi Komitmen maka dinyatakan bahwa Hipotesis kedua (H2) diterima.

3. Hasil penelitian ini menunjukkan nilai koefisien korelasi antara Gaya Kepemimpinan dan Eskalasi Komitmen sebesar 0.150 dengan tingkat signifikan sebesar 0.136. Hal ini menunjukkan bahwa Gaya Kepemimpinan memiliki pengaruh positif dan tidak signifikan terhadap Eskalasi Komitmen maka dinyatakan bahwa Hipotesis ketiga (H3) ditolak 
Vol. 10, No. 1 (Juni 2021)

Dwi Prihatini

DOI: http://dx.doi.org/10.26418/jaakfe.v10i1.46713

Hal 19-43

\section{Pembahasan}

\section{Pengaruh Adverse Selection Terhadap Eskalasi Komitmen}

Hasil penelitian ini menunjukkan nilai koefisien korelasi antara Adverse Selection dan Eskalasi Komitmen sebesar 0.100 dengan tingkat signifikan sebesar 0.234. Hal ini menunjukkan bahwa Adverse Selection tidak memiliki pengaruh terhadap Eskalasi Komitmen maka dinyatakan bahwa Hipotesis pertama (H1) ditolak. Hasil penelitian ini sejalan dengan menjelaskan Teori Keagenan yang berhubungan dengan masalah Eskalasi Komitmen kondisi ini terjadi karena asimetri informasi yang terjadi antara prinsipal dan agen sehingga informasi yang diperoleh prinsipal kurang lengkap dan tidak dapat menjelaskan kinerja agen yang sesungguhnya dalam mengelola kekayaan. Prinsipal yang dipercayakan kepada agen. Berdasarkan teori ini hubungan antara pemilik dan manajer pada dasarnya sulit tercipta karena adanya kepentingan yang saling bertentangan. Dari sudut pandang teori keagenan, prinsipal (pemilik) membawahi agen (karyawan atau manajer yang lebih rendah) untuk melaksanakan kinerja yang efisien. Sehingga apabila ada ketumpang tindihan dalam penerimaan teori ini, maka akan terjadi bentrokan dalam melakukan upaya untuk terjadinya eskalasi komitmen pada perusahaan.

Hasil penelitian mendukung dengan penelitian yang dilakukan Sari (2017) yang menyatakan bahwa ketika seorang manajer yang memiliki informasi privat yang tidak diketahui orang lain dalam perusahaan ditambah dengan terdapat kesempatan untuk melalaikan tugas (incentive to shirk) bagi manajer, maka keputusan yang dibuat oleh manajer cenderung untuk melanjutkan proyek investasi yang tidak menguntungkan. Hasil penelitian ini juga mendukung atau sesuai dengan penelitian sebelumnya yang dilakukan oleh Akbar (2018) bahwa ketika seorang manajer memiliki informasi superior yang tidak dimiliki oleh prinsipal maka manajer tersebut akan cenderung berhati-hati memberikan informasi. Asimetri informasi, seperti ini yang memicu manajer untuk bereskalasi demi mempertahankan kepentingan pribadinya. Jika informasi lengkap dalam kondisi incentive to shirk manajer akan cenderung memilih untuk tidak melanjutkan proyek yang tidak menguntungkan atau merugikan karena hal ini akan segera diketahui oleh pemilik perusahaan. Sedangkan, jika manajer memiliki informasi privat, pemilik perusahaan tidak bisa mengawasi manajer secara keseluruhan maka pada kondisi ini manajer yang memiliki incentive to shirk akan cenderung untuk melanjutkan proyek yang tidak menguntungkan atau mengindikasikan kegagalan.

Kondisi ketika manajer memiliki informasi privat yang tidak dimiliki orang lain dalam perusahaan dan terdapat kesempatan untuk melalaikan tugas bagi manajer tersebut dapat dikatakan sebagai suatu kondisi Adverse Selection. Dalam hal ini ketika seorang manajer mendapat Adverse Selection maka keputusan yang dibuat oleh manajer tersebut akan cenderung melanjutkan proyek investasi yang tidak menguntungkan.

\section{Pengaruh Negative Framing Terhadap Eskalasi Komitmen}

Hasil penelitian ini menunjukkan bahwa Negative Framing signifikan terhadap Eskalasi Komitmen dengan nilai koefisien 0.546 dengan tingkat signifikansi sebesar 0.001 dengan hasil tersebut, maka hipotesis kedua $(\mathrm{H} 2)$ diterima. Hasil penelitian ini mendukung Teori 
Vol. 10, No. 1 (Juni 2021)

Dwi Prihatini

DOI: http://dx.doi.org/10.26418/jaakfe.v10i1.46713

Hal 19-43

Prospek bahwa Negative Framing diproksikan dengan penyajian informasi mengenai kerugian yang pasti. Pengaruh sunk cost ternyata berperan cukup besar dalam proses pengambilan keputusan untuk tetap melanjutkan suatu investasi yang dianggap kurang menguntungkan. Sunk cost adalah biaya yang sudah terjadi di masa lalu dan tidak akan muncul lagi dari suatu proyek atau investasi baru.

Hasil penelitian ini juga sesuai dengan penelitian yang dilakukan oleh Sari dan Wirakusuma (2016) yang menyatakan mampu membuktikan bahwa informasi yang disajikan dalam negative framing mampu mempengaruhi pengambil keputusan (manajer) untuk melakukan eskalasi terhadap komitmennya yang dalam hal ini diukur dengan pertimbangan untuk melanjutkan proyek yang mengindikasikan kegagalan. Hasil penelitian ini juga konsisten dengan penelitian Salter dan Sharp (2004) melakukaneksperimen dengan menggunakan manajer di AS dan Kanada dan menemukan hasil bahwa negative framing meningkatkan kemungkinan eskalasi komitmen.

\section{Pengaruh Gaya Kepemimpinan Terhadap Eskalasi komitmen}

Hasil penelitian ini menunjukkan nilai koefisien korelasi antara Gaya Kepemimpinan dan Eskalasi Komitmen sebesar 0.100 dengan tingkat signifikan sebesar 0.234. Hal ini menunjukkan bahwa Gaya Kepemimpinan tidak memiliki pengaruh terhadap Eskalasi Komitmen maka dinyatakan bahwa Hipotesis ketiga (H3) ditolak. Gaya Kepemimpinan seorang manajer berpengaruh pada pengambilan keputusan untuk melanjutkan atau menghentikan proyek investasi yang tidak menguntungkan bagi perusahaan.

Hasil penelitian ini mendukung teori Gaya Kepemimpinan otoriter Hasibuan (2016:172) yaitu segala kebijakan dan keputusan terpusat pada pemimpin artinya bawahan hanya melaksanakan tugas yang telah diberikan oleh seorang pemimpin. Gaya Kepemimpinan yang dimiliki oleh setiap manajer akan menentukan bagaimana kinerja staf akan terjadi di sebuah perusahaan seperti dapat mempengaruhi motivasi dan orientasi kerja pegawai perusahaan, sehingga meskipun memiliki dampak terhadap Eskalasi Komitmen namun kecil karena adanya sebuah kepercayaan untuk bangun dari kondisi yang terpuruk tidak serta merta hanya berada di tangan manajer peran andil dan rasa loyalitas yang diciptakan oleh staf juga sangat mempengaruhi sehingga berdampak kecil terhadap Eskalasi Komitmen. penelitian ini berbeda dengan penelitian yang dilakukan oleh Jasrul (2015) negatif dan tidak berpengaruh dimungkinkan karena partisipan yang menjadi subjek penelitian belum memiliki pengalaman kerja yang terlibat langsung dalam pengambilan keputusan investasi sehingga partisipan belum mengerti Gaya Kepemimpinan Manajer yang bagaimana yang akan diterapkan dalam pengambilan keputusan Investasi untuk mencegah diri melakukan Eskalasi Komitmen dalam pengambilan keputusan investasi.

\section{SIMPULAN, REKOMENDASI DAN SARAN}

Tujuan penelitian ini adalah untuk menguji dan menganalisis pengaruh Adverse Selection, Negative Framing dan Gaya Kepemimpinan terhadap Eskalasi Komitmen. Teknik analisis data dilakukan dengan metode Structural Equation Modeling (SEM) dengan pendekatan Partial Least Square (PLS) menggunakan WarpPLS 6.0. Data yang diolah dalam 
Vol. 10, No. 1 (Juni 2021)

Dwi Prihatini

DOI: http://dx.doi.org/10.26418/jaakfe.v10i1.46713

Hal 19-43

eksperimen penelitian adalah 50 partisipan mahasiswa prodi Akuntansi Fakultas Ekonomi dan Bisnis Universitas Tanjungpura.

Berdasarkan hasil analisa data menggunakan software WarpPLS 6.0 dapat disimpulkan bahwa:

1. Adverse Selection tidak memiliki pengaruh terhadap eskalasi komitmen, hal ini terjadi karena ada ketumpang tindihan dalam penerimaan informasi antara pemilik dan manajer, manajer cenderung mendapatkan informasi yang lebih cepat dibandingkan pemilik, sehingga hal ini akan mempengaruhi orientasi tujuan, maka akan terjadi bentrokan dalam melakukan upaya untuk terjadinya Eskalasi Komitmen pada perusahaan.

2. Negative Framing signifikan terhadap eskalasi komitmen, hal ini terjadi karena Negative Framing mampu mempengaruhi pengambil keputusan (manajer) untuk melakukan eskalasi terhadap komitmennya yang dalam hal ini diukur dengan pertimbangan untuk melanjutkan proyek yang mengindikasikan kegagalan.

3. Gaya Kepemimpinan tidak memiliki pengaruh terhadap eskalasi komitmen, hal ini terjadi karena Gaya Kepemimpinan yang dimiliki oleh setiap manajer akan menentukan bagaimana kinerja staf akan terjadi di sebuah perusahaan seperti dapat mempengaruhi motivasi dan orientasi kerja pegawai perusahaan, sehingga meskipun memiliki dampak terhadap Eskalasi Komitmen namun kecil karena adanya sebuah kepercayaan untuk bangun dari kondisi yang terpuruk tidak serta merta hanya berada di tangan manajer peran andil dan rasa loyalitas yang diciptakan oleh staf juga sangat mempengaruhi sehingga berdampak kecil terhadap Eskalasi Komitmen.

Beberapa saran yang diberikan dalam penelitian selanjutnya adalah:

1. Penelitian selanjutnya diharapkan menggunakan partisipan manajer sesungguhnya bukan subjek mahasiswa, karena apabila menggunakan subjek mahasiswa kemungkinan terjadi bias penelitian sangatlah besar karena mahasiswa cenderung acuh saat dijadikan partisipan penelitian.

2. Peneliti bisa dikembangkan menggunakan variabel lainnya yang mempengaruhi eskalasi komitmen seperti ukuran perusahaan, bias, dan lain-lain.

3. Terdapat jawaban netral yang seharusnya tidak digunakan dalam penelitian karena dapat menimbulkan multi tafsir.

\section{REFERENSI}

Amylin. (2003). "Pengaruh Tanggung Jawab dan Pertimbangan Etis Manajer Terhadap Judgement Evaluasi Keputusan Investasi Ketika Terjadi Adverse Selection”. Tesis tidak diterbitkat. Magister Sains dan Doktor Fakultas Ekonomi dan Bisnis Universitas Gadjah Mada. Analysis of framing effects. Organizational Behavior and Human Decision Processes 76: 149-188.

Anam, M. Z. (2013). Pengaruh Gaya Kepemimpinan Manajer dan Motivasi Kerja Karyawan Terhadap Kinerja Karyawan Pada Bengkel Jasatec Cabang Gombong. Yogyakarta. Program Studi Akuntansi DIII Fakultas Ekonomi Universitas Negeri Yogyakarta 2013.

Akbar, R. (2018). Pengaruh Adverse Selection Dan Negative Framing Terhadap Eskalasi Komitmen Pada Keputusan Investasi. Yogyakarta. Program Studi Perbankan Syariah 
Vol. 10, No. 1 (Juni 2021)

Dwi Prihatini

DOI: http://dx.doi.org/10.26418/jaakfe.v10i1.46713

Hal 19-43

Fakultas Ekonomi dan Bisnis Islam Universitas Islam Negeri Sunan Kalijaga Yogyakarta.

Chong, Vincent K. \& Surwayati, Rindah F. (2010). "De-escalation strategis: The impact of job rotation and monitoring control on manager's project evaluation decisions". JAMAR. Vol. 8. No. 2. $\mathrm{p}: 39-50$.

Copper, Donald, R; Schindler, Pamela S. (2007). business Research Methods; McGraw-Hill, Irwin, Boston.

Dubrin, Andrew J. (2013). Proactive Personality and Behavior For Individual and Organization. Yogyakarta: BPFE

Efda, R. A. dan Dwita, S. (2019). Pengaruh Informasi Investasi dan Overconfidence Terhadap Eskalasi Komitmen. Padang. Universitas Negeri Padang.

Fajrin. dan Susilo. (2018). Pengaruh Gaya Kepemimpinan Terhadap Kinerja Karyawan Dengan Motivasi Kerja Sebagai Variabel Intervening. Malang. Fakultas Ilmu Administrasi Universitas Brawijaya.

Ghozali, I. (2006). Aplikasi Analisis Multivariate Dengan Program SPSS. Cetakan Keempat. Semarang: Badan Penerbit Universitas Diponegoro.

Gudono. (2012). Teori Organisasi. Edisi 2. Yogyakarta: BPFE

Hartono, J. \& Abdilah, W. (2014). Partial Least Square (PLS). Yogyakarta. Andi

Handoko, T. Hani. (2012). Manajemen. Edisi 2. Yogyakarta: BPFE. 9-74.

Hasibuan, Malayu S.P. 2016. Manajemen Sumber Daya Manusia. Jakarta: PT Bumi Aksara.

Jasrul, A. N. (2015). Pengaruh Gaya Kepemimpinan Manajer dan Keefektifan Monitoring Control Terhadap Eskalasi Komitmen Dalam Pengambilan Keputusan Investasi (Tesis yang tidak dipublikasikan), Universitas Negeri Yogyakarta, Indonesia.

Jesica Handoko. (2006). "Pengaruh Tanggung Jawab dan Locus of Control dalam Keputusan Investasik Pouring Good Money After Bad.” Ekuitas. Vol.10 pp:537-551.

Jasrul. (2015). Pengaruh Gaya Kepemimpinan Manajer dan Keefektifan Monitoring Control Terhadap Eskalasi Komitmen Dalam Pengambilan Keputusan Investasi. Yogyakarta. Universitas Negeri Yogyakarta.

Keil, M., M. Joan, \& R. Arum. 2000. Why Sofware Projects Escalate: An

Kholmi, M. (2010. Akuntabilitas Dalam Perspektif Teori Agensi. Malang: Fakultas Ekonomi Universitas Muhammadiyah Malang.

Lubis Arfan Ikhsan. (2010). Akuntansi keprilakuan. Edisi 2. Jakarta: Salemba Empat

Nawawi, H. Hadari. 2003. Kepemimpinan Mengefektifkan Organisasi. Yogyakarta: Gajah Mada University Press.

Nawawi, H. Hadari. 2003. Kepemimpinan Mengefektifkan Organisasi. Yogyakarta: Gajah Mada University Press.

Pengambilan Keputusan Strategik: Suatu Studi Eksperimental, Simposium

Putri, R. 2009. 10 Aspek Penting dalam Capital Budgeting (Juli 2011).

Rivai, Veithzal, dkk. 2009. Kepemimpinan Dan Perilaku Organisasi. Edisi Ketiga. Jakarta: PT. Raja Grafindo Persada.

Salter, S. B. dan D. J. Sharp. 2004. The Determinants of Escalation Commitment: National Culture and Experience Effects. University of Cincinnati. (Juli 2011). 
Vol. 10, No. 1 (Juni 2021)

Dwi Prihatini

DOI: http://dx.doi.org/10.26418/jaakfe.v10i1.46713

Hal 19-43

Sholihin, M., \& Ratmono, D. (2013). Analisis SEM-PLS dengan WarPLS 3.0 untuk Hubungan Nonlinier dalam Penelitian Sosial dan Bisnis. Yogyakarta: Andi

Shulz, Axel K. D. and Mandy M. Cheng. (2002). "persesitance in capital budgeting Reinvestment decisions-personal responsibility antecendent and information asymmetry moderator: A note". Accounting and finance, 42: pp. 73-86.

Sodikin, S. S. (2015). Akuntansi Managemen Sebuah Pengantar. Yogjakarta: UPP STIM YKPN.

Solimun, Dr, IR, MS, \& Fernandes, Dr. Adji. A. R. S. Si, M.Sc. (2017). Metode Statistika Multivariat Pemodelan Persamaan Struktural (SEM) Pendekatan WarpPLS. Malang :UB Press.

Sari. dan Wirakusuma (2016). Pengaruh Adverse Selection dan Negative Framing Pada Kecenderungan Eskalasi Komitmen. Bali. Fakultas Ekonomi dan Bisnis Universitas Udayana (UNUD).

Suartana, I. W. 2005. Model Framing dan Belief Adjustment dalam Menjelaskan Bias Pengambilan Keputusan Pengauditan, imposium Nasional Akuntansi VIII, Solo, September.

Sugiyono. (2017). Metode Penelitian Bisnis. Bandung: Alfabeta.

Tanjung Rizkiano. (2012). "Strategi Pemberian Informasi Akuntansi Untuk Mengurangi Eskalasi Komitmen”. Jurnal Ilmiah Manajemen Akuntansi Vol. 1, No. 4, Hal: 27.

Thoha, Miftah. (2012). Perilaku Organisasi. Jakarta : PT. Raja Grafindo Persada.

Yusnaini, 2005, Analisis Framing dan Causal Cognitive Mapping Dalam 